Copyright (C) 2016 by Academic Publishing House Researcher

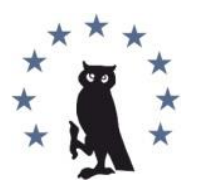

Published in the Russian Federation

European Researcher

Has been issued since 2010.

ISSN 2219-8229

E-ISSN 2224-0136

Vol. 103, Is. 2, pp. 69-86, 2016

DOI: 10.13187/er.2016.103.69

www.erjournal.ru

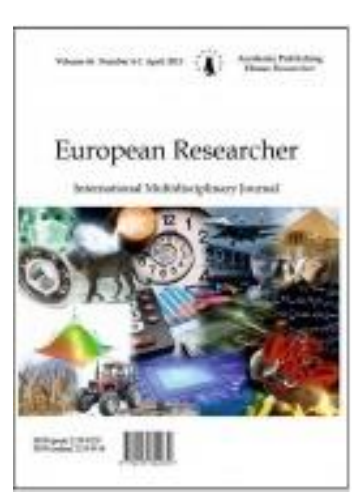

UDC 33

\title{
The Energy Partnership between Russia and the Countries of Northeast Asia
}

\author{
${ }^{1}$ Sergei M. Nikonorov \\ ${ }^{2}$ Youngmin Yoon \\ 1-2 Moscow State University named after M.V. Lomonosov, Russian Federation \\ ${ }^{1}$ Dr. (Economy), associate professor \\ E-mail:nico.73@mail.ru \\ ${ }^{2}$ graduate student
}

\begin{abstract}
The study tries to answer the most fundamental question of energy cooperation between Russia and the countries of Northeast Asia, "Do we really need a model of cooperation in the energy sector?". This question is important for understanding the aspects of energy cooperation in the region, because the idea of creating this cooperation is based on the assumption that there is complementarity and interdependence between the structures of supply and demand of these countries offer. To find the answer to this question, we analyzed the sectors of demand, consumption, and Russian proposals and the countries of Northeast Asia oil and gas, as the current dominant energy sources, and renewable energy sectors considered (renewable energy sources), as a potential future sources.

Keywords: energy strategy, energy cooperation model, renewable energy, social and environmental concerns, complementarity and interdependence in the energy sector.

\section{Introduction}

Since collapse of USSR there is a hopeful idea that Russian energy resources will save Northeast Asian countries suffering from insufficient energy resources. High energy consuming socioeconomic structure and import depended primary energy supply structure of S. Korea, Japan and China have made them to seek cooperation with Russia in energy sphere at bilateral and multilateral levels. At the same time among Russian intelligentsia and policy makers, also an idea has grown that the northeastern countries could be a promising market for its energy resources. This strong complementarity in supply and demand sides of the NEA countries have considered as motivating power to build active cooperation in energy sector and it has seemed realized soon. However, the results are disappointed until this moment. Of course, there are some achievements, such as LNG imports of S. Korea and Japan from Vladivostok and ESPO oil pipeline project between Russia and China, but considering their hope and what they have discussed at country level, they are too small achievements. So, this paper begins very fundamental questions, which is "do they really need regional energy cooperation?" or "do their energy supply and consumption structures have complementarity to each other?" In order to answer for these questions, we are going to analyze NEA countries' energy status focusing on oil, natural gas and renewable energy sources. The reason why we focus on these energy sources is that these energy sources have the
\end{abstract}


critical role in the countries' present and future energy status. Oil has dominant share in the countries' energy supply and consumption. As the most important resource in industry sector, it maintains its significant position in national economy at least for one or two decades despite of criticism from the ecologist-side and challenge from new energy resources. Natural gas has increased its share in global and NEA countries' energy mix due to its 'relatively cleaner' characteristic, emitting $\mathrm{CO}_{2}$ less than oil and coal. Renewable energy sources are undoubtedly future of the countries' energy sector. As like other developed and developing countries in the world, NEA countries are seeking to develop renewable energy sector as their national agenda.

In the following chapter, production and exports of Russia in crude oil and natural gas are explored. High capacity of Russia's oil and gas exports is the one of the main pillars for the complementarity. We are going to check historical trends, forecasts and features of Russian oil and gas production, as well as exports. In third chapter, trends and forecast of consumption and imports in the energy sources of S. Korea, Japan and China are studied. In forth chapter, these 4 countries' features in production and consumption of renewable energy sources (RES) are analyzed.

Diverse statistical data from IEA, Enerdata, British Petroleum, energy agencies of NEA countries, related academic and business works are used for our work. Among them, we are going to follow IEA's official statistics, 'Energy Statistics of OECD countries 2014' and 'Energy Statistics of non-OECD countries 2014', as main data.

\section{Structure of Russian Energy resource production and exports}

\section{Dynamics of oil and gas production since 1985 and forecast}

Russia's crude oil production has marked the peak in 1987 and dramatically fallen by end of 1990's. Since 2000, its oil production have been recovering and marked 534.1 million tons in 2014, but still under its peak in 1987. Its proved reserve is estimated $15.6 \mathrm{Tcm}$ (Trillion cubic meter) in 2014, but the reserve seems on the declining curve since 1991, when it marked over $17 \mathrm{Tcm}$. As the production is increasing and the reserve is decreasing, its $\mathrm{R} / \mathrm{P}$ ratio (reserve to production) is falling by under 30 (29.3 in 2014).

Forecast of Russian oil production is unclear. According to "Energy Strategy of Russia for the Period up to 2035", Russian annual oil production will remain at current level or decrease by 476 million tons by 2035. As we see in the [Figure 1], Russian oil production is catching up rapidly its production level in Soviet era for the past decade, but the motive factors for the fast recovery could be the reasons for the future decrease. In other words, the rapid production recovery of Russian oil sector in 2000's is due to overexploitation of the cost-effective oil fields in private sector and it made the cost-effective oil fields exhausted soon.* In addition to this, another Russian governmental document supports the pessimistic prospect. "General Scheme of Development of the Oil Industry up to 2020" foresees declining oil production in the future. In scenario 'planned', assuming oil-producing companies maintain current level of output, the total production will drop dramatically. In scenario 'designed', supposing the government adopts good policy and investment into the sector increase significantly, the output will increase by 2017 and slowly decrease by 2030. The fact, production record after 2009, seems support the very optimistic forecast in the "Energy Strategy" up to this time, but considering ages of current major oi producing fields in Russia and its decreasing $\mathrm{R} / \mathrm{P}$ ratio, rapid drop in Russian oil production is also possible. In other words, there will be no producing-surprise in Russian oil production and even it could be drop.

\footnotetext{
${ }^{*}$ See, for more details on Russian oil production : WojciechKononczuk, Russia's Best Ally: The situation of the Russian oil sector and forecast its future, OSW Studies, no. 39, 2012
} 


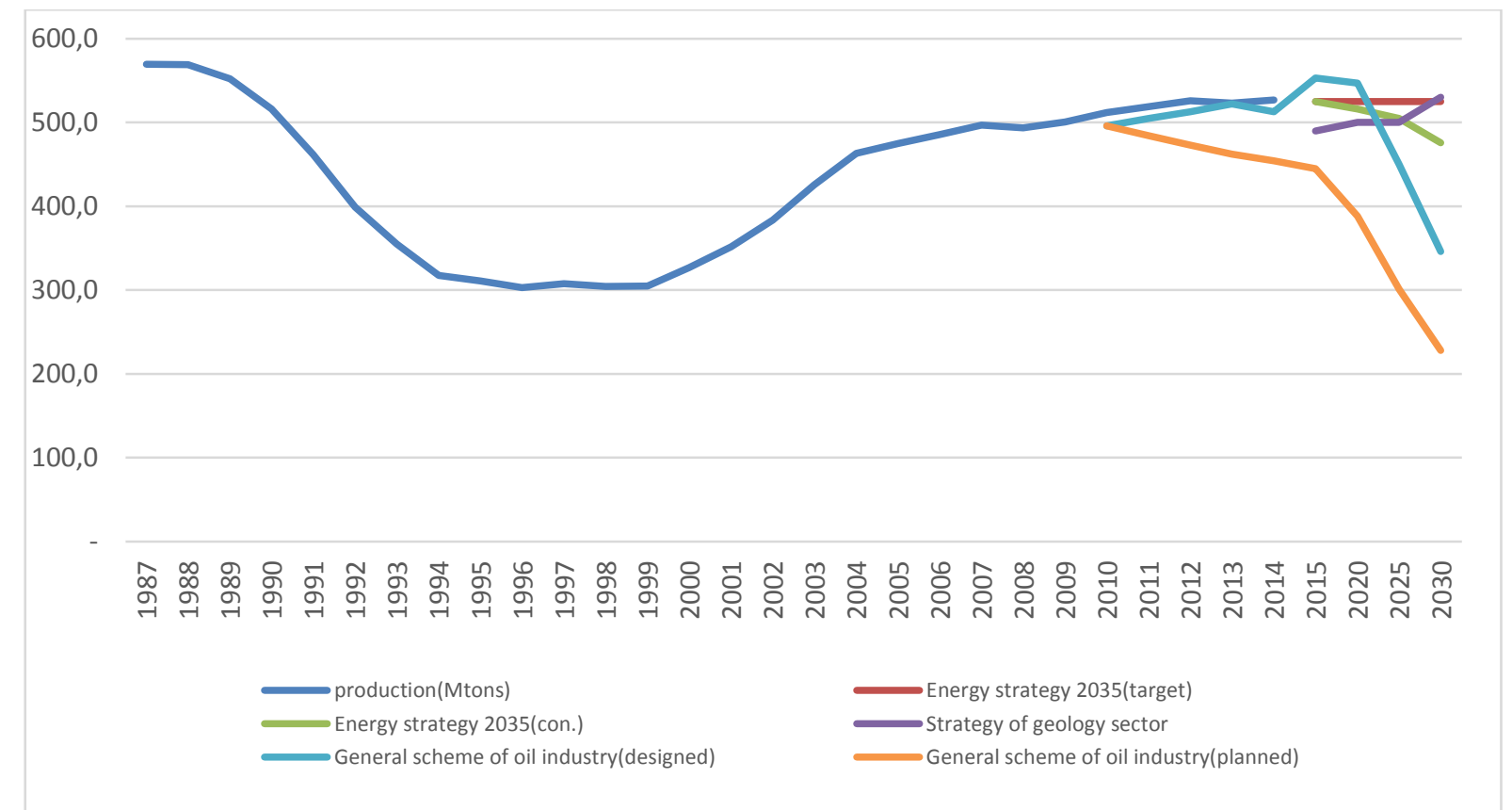

Source: Wojciech Kononczuk, Russia's Best Ally: The situation of the Russian oil sector and forecast its future, OSW Studies, no. 39, 2012. / BP Statistical review 2015

Figure 1. Russian oil production since 1985 and official forecasts (mtons)

In terms of geography, most of Russian oil production comes from western part of the country. In European part provides around 30\% of total production, but its share of total output has slowly and continuously declined due to shrinking output in South Khylchuyuskoye oil field in Timan-Pechora. ${ }^{*}$ Production of North Caucasus region is also reducing, but losses in those regions in European part have been compensated by rising output in Ural-Volga region.

Table 1: Oil production of Russia by region

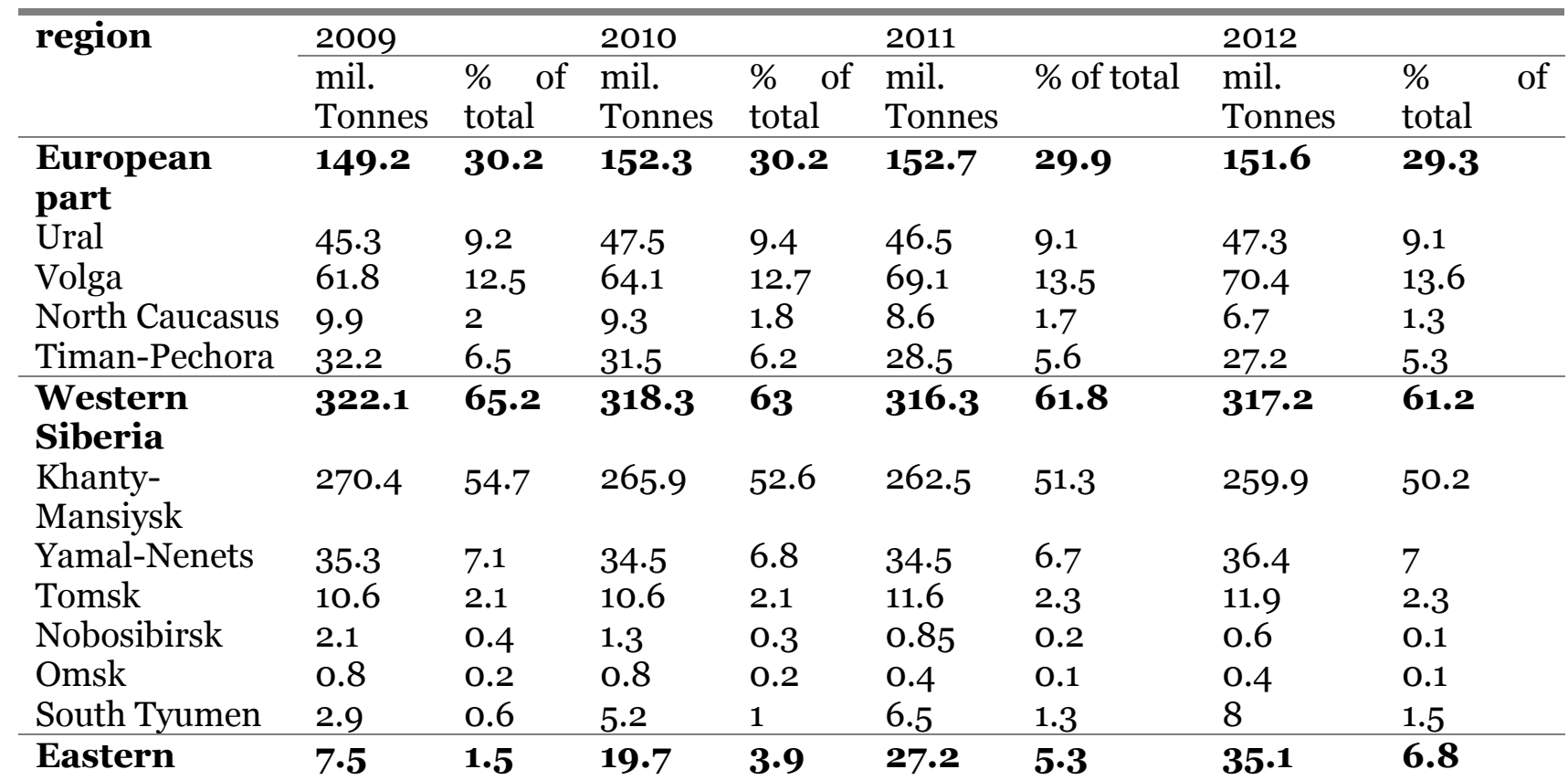

${ }^{*}$ L.V. Eder, L.V. Eder I.V. Filimonova, V.YU. Nemov, I. A. Provornyy, Production, processing and export of oil and oil products in Russia, Bulletin of the Tyumen State University. 2014. № 4. Earth sciences, p. 87. 


\begin{tabular}{lllllllll}
\hline Siberia & & & & & & & \\
Krasnoyarsk & 3.4 & 0.7 & 12.9 & 2.5 & 15.1 & 3 & 18.5 & 3.6 \\
Irkutsk & 1.6 & 0.3 & 3.3 & 0.7 & 6.5 & 1.3 & 9.9 & 1.9 \\
Saha republic & 2.5 & 0.5 & 3.5 & 0.7 & 5.6 & 1.1 & 6.7 & 1.3 \\
\hline Far east & $\mathbf{1 5 . 4}$ & $\mathbf{3 . 1}$ & $\mathbf{1 4 . 8}$ & $\mathbf{2 . 9}$ & $\mathbf{1 5 . 2}$ & $\mathbf{3}$ & $\mathbf{1 4 . 2}$ & $\mathbf{2 . 7}$ \\
Sahalin & 15.4 & 3.1 & 14.8 & 2.9 & 15.2 & 3 & 14.2 & 2.7 \\
\hline Russia, Total & $\mathbf{4 9 4 . 2}$ & $\mathbf{1 0 0}$ & $\mathbf{5 0 5 . 1}$ & $\mathbf{1 0 0}$ & $\mathbf{5 1 1}$ & $\mathbf{1 0 0}$ & $\mathbf{5 1 8}$ & $\mathbf{1 0 0}$ \\
\hline
\end{tabular}

Source: L.V. Eder I.V. Filimonova, V.YU. Nemov, I. A. Provornyy, Production, processing and export of oil and oil products in Russia, Bulletin of the Tyumen State University. 2014. № 4. Earth sciences. 83-97

Western Siberia is the main pillar of the Russian oil industry. It has been supplying more than $60 \%$ of oil production since Soviet era. Despite of continuous production since 1964, this region still has around half of Russia's oil deposits, including eight of ten largest oil fields in Russia*. In 2012, its output have increased due to technological advance, but its share in total has steadily decreased from $71 \%$ in 2004 to $61.2 \%$ in 2012. As we see in the [Table 1], those two regions produce more than $90 \%$ of total output. Eastern Siberia and Far East still have small share in production, although output in Eastern Siberia has increased rapidly since 2009. In 2010, it produced more than double of output in 2009. In 2012, it shows 35.1 million tons of output, which is 4.68 times higher than output in 2009 and takes 6.1\% of total production in 2012.

Meanwhile, Russian proved natural gas reserve is estimated $32 . T \mathrm{~cm}$, which is world $2^{\text {nd }}$ after Iran and takes $17.4 \%$ of world total. ${ }^{\dagger}$ It has been maintaining about $30 \mathrm{Tcm}$ since 1991 . Russian reserve to production ratio ( $\mathrm{R} / \mathrm{P}$ ratio) in natural gas has been showing quite stable tendency since 1991, around middle of 50. In the same period USA's R/P ratio has risen from 9.5 to 13.4, Iran's and Qatar's R/P ratio have decreased from 640 to 197 and from 842 to 138. In 2014, Russia produced $578 \mathrm{bcm}$ natural gas, which takes $16.7 \%$ of world total.

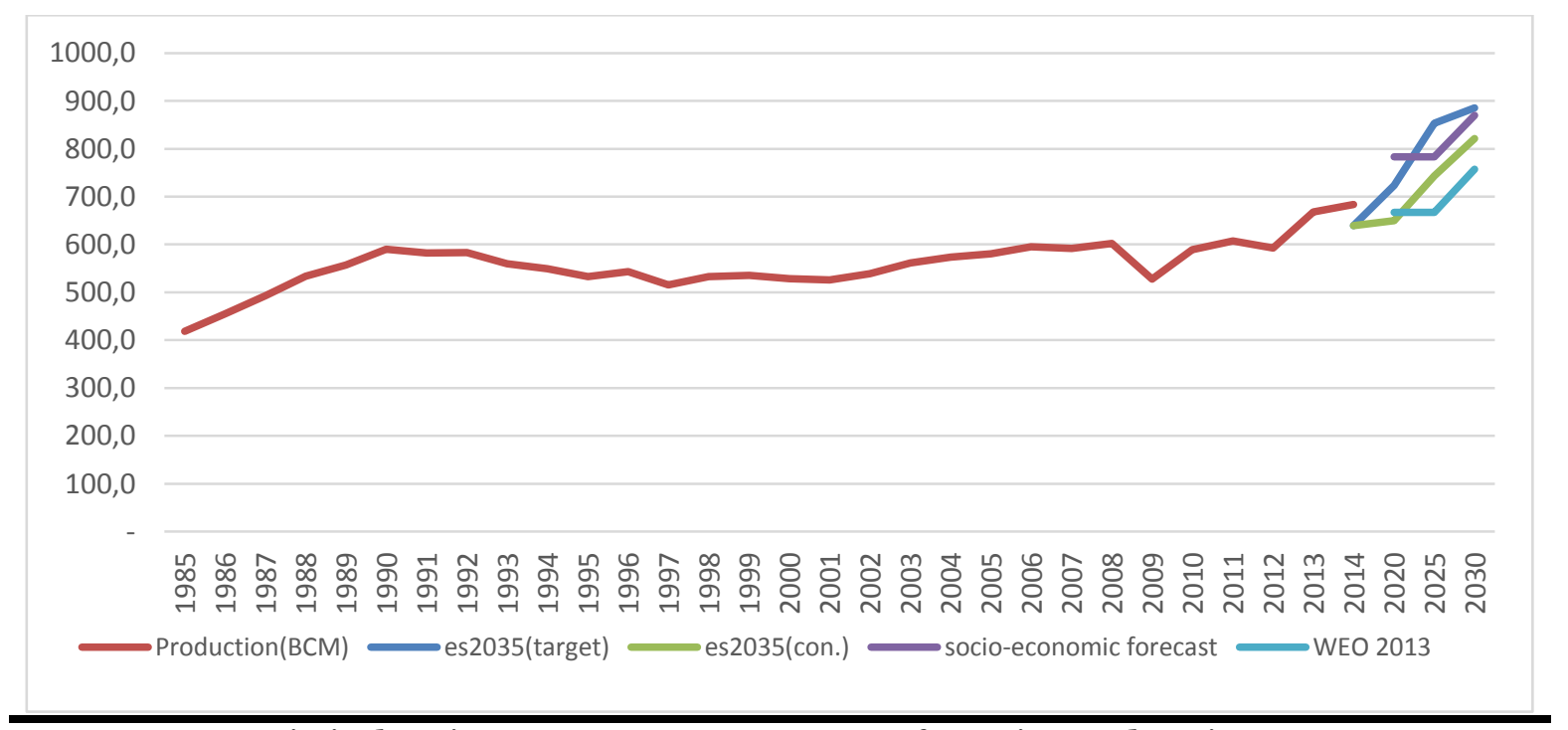

Source: BP Statistical review 2015, Energy Strategy of Russian Federation up to 2035, World Energy Outlook 2013, Forecast of Long-term Socio-economic development of Russia up to 2030

Figure 2. Russian natural gas production since 1985 and official forecasts (bcm)

\footnotetext{
"Wojciech Kononczuk, Russia's Best Ally: The situation of the Russian oil sector and forecast its future, OSW Studies, no. 39, 2012, p. 18.

${ }^{\dagger}$ According to BP statistical review of world energy 2015. EIA, Oil and Gas Journal estimate that Russian reserve is bigger than Iran's.
} 
According to diverse Russian official forecasts, total output of natural gas will increase by 2035 as we see in [figure 2]. Among them, "Energy Strategy of Russian Federation up to 2035", the latest forecast, indicates that the production will increase by 821 (conservative) to 885 (target) bcm by 2035. In former version of the strategy, "Energy Strategy up to 2030" approved in 2008, the production level was predicted 940 bcm by 2030, but it had to be revised by recent unfavorable environments, such as lower domestic and external demand, which was exacerbated by slow recovery of price in foreign markets and the inhibition of domestic gas price increases*and economic sanction against Russia by western world. According to the Energy Research Institute of the Russian Academy of Science, volume of Russian gas reserve and its structure is favorable for increasing future production and it also predicts the outcome could increase to $970 \mathrm{bcm}$ in maximum by 2040. Russian government's "Socio-Economic forecast" and IEA's forecast in "World Energy Outlook 2013" also predict growing production at different levels. In terms of geography, most volume of Russian gas production comes from western side of the country like its oil production. Western Siberia and European Basin have taken more than 90\% of Russian total gas production. Especially, Western Siberia, in which included Nadym-Purtazovsky, the biggest Russian gas mining field has conducted absolute role in Russian natural gas production. According to "Energy Strategy of Russia to 2035", share of Western Siberia in total gas production will decrease steadily by 2035 from $85.3 \%$ in 2014 to $77.3 \%$ in 2035. Unlike Western Siberia, Eastern Siberia and Far East will increase its production volume and share in total rapidly from $41 \mathrm{bcm}$ (6.4\% of total) in 2014 to $135 \mathrm{bcm}$ (13.5\% of total) in 2035 .

Table 2: Forecast of Russian Gas production by region

\begin{tabular}{|c|c|c|c|c|c|c|c|c|c|c|c|c|c|c|}
\hline \multirow[b]{3}{*}{ region } & \multicolumn{2}{|c|}{2014} & \multicolumn{4}{|c|}{2020} & \multicolumn{4}{|c|}{2025} & \multicolumn{4}{|c|}{2035} \\
\hline & \multirow[b]{2}{*}{$\mathrm{bcm}$} & \multirow[b]{2}{*}{$\%$} & \multicolumn{2}{|c|}{ con. } & \multicolumn{2}{|c|}{ target } & \multicolumn{2}{|c|}{ con. } & \multicolumn{2}{|c|}{ target } & \multicolumn{2}{|c|}{ con. } & \multicolumn{2}{|c|}{ target } \\
\hline & & & $\mathrm{bcm}$ & $\%$ & $\mathrm{bcm}$ & $\%$ & $\mathrm{bcm}$ & $\%$ & $\mathrm{bcm}$ & $\%$ & $\mathrm{bcm}$ & $\%$ & $\mathrm{bcm}$ & $\%$ \\
\hline $\begin{array}{l}\text { Western } \\
\text { Siberia }\end{array}$ & 546 & $\begin{array}{c}85 . \\
3\end{array}$ & 544 & $\begin{array}{c}83 . \\
7\end{array}$ & $\begin{array}{c}60 \\
6\end{array}$ & $\begin{array}{c}83 . \\
7\end{array}$ & $\begin{array}{c}59 \\
2\end{array}$ & 79.7 & 679 & $\begin{array}{c}79 . \\
6\end{array}$ & $\begin{array}{c}65 \\
0\end{array}$ & $\begin{array}{c}79 . \\
2\end{array}$ & 683 & $\begin{array}{r}77 . \\
3 \\
\end{array}$ \\
\hline $\begin{array}{c}\text { Europea } \\
\text { n basin }\end{array}$ & 47 & $7 \cdot 3$ & 53 & 8.2 & 52 & 7.2 & 50 & 6.7 & 55 & 6.4 & 47 & $5 \cdot 7$ & 52 & 5.9 \\
\hline $\begin{array}{c}\text { Eastern } \\
\text { Siberia } \\
\text { and Far } \\
\text { East }\end{array}$ & 41 & 6.4 & 47 & 7.2 & 57 & 7.9 & 89 & $\begin{array}{c}12 . \\
0\end{array}$ & 106 & 12.4 & 111 & 13.5 & 135 & $15 \cdot 3$ \\
\hline est. & 6 & 0.9 & 6 & 0.9 & 9 & 1.2 & 12 & 1.6 & 13 & 1.5 & 13 & 1.6 & 14 & 1.6 \\
\hline Total & $\begin{array}{c}64 \\
0\end{array}$ & & $\begin{array}{c}65 \\
0\end{array}$ & & 724 & & 743 & & $\begin{array}{c}85 \\
3\end{array}$ & & 821 & & $\begin{array}{c}88 \\
4\end{array}$ & \\
\hline
\end{tabular}

Source: Energy Strategy of Russian Federation up to 2035

\section{Dynamics of Russian oil and gas exports}

A striking feature of Russian oil exports is its dependency on European market. As [Figure 3] shows, more than $61 \%$ of its total exported oil goes to Europe. In 2014, Russia exports $11 \%$ of its total exported crude oil to Germany and 10\% to Netherland. Poland, Italy, Finland and Sweden follow. Asian market is already important for Russian oil export. It takes $26 \%$ of Russian total oil export and its share in total grows steadily. China is the biggest customer of Russian oil. It imports $14 \%$ of total Russian oil export in 2014. Japan and S. Korea follow with share of $6 \%$ and $2 \%$.We can see rising share of Asian market in Russian oil export by destination. Share of European market has decreased slowly since 2000. On the other hand, share of Asian market in Russian oil export has grown from $12 \%$ in 2000 to $22 \%$ in 2013 . Undoubtedly, China is the main contributor for this

\footnotetext{
${ }^{*}$ The Energy Research Institute of the Russian Academy of Science, Global and Russian Energy outlook to 2040, Analytical Centre of the Government of Russian Federation, 2014, p. 140.
} 
fast growing share of Asia. Its share of Russian total oil export by destination was just $0.99 \%$ in 2000, but in 2013, the number have reached to $10 \%$ of total. Share of Japan and S. Korea also have grown from $0 \%$ and $0.56 \%$ each in 2000 to $5.20 \%$ and $3.50 \%$ in 2013.

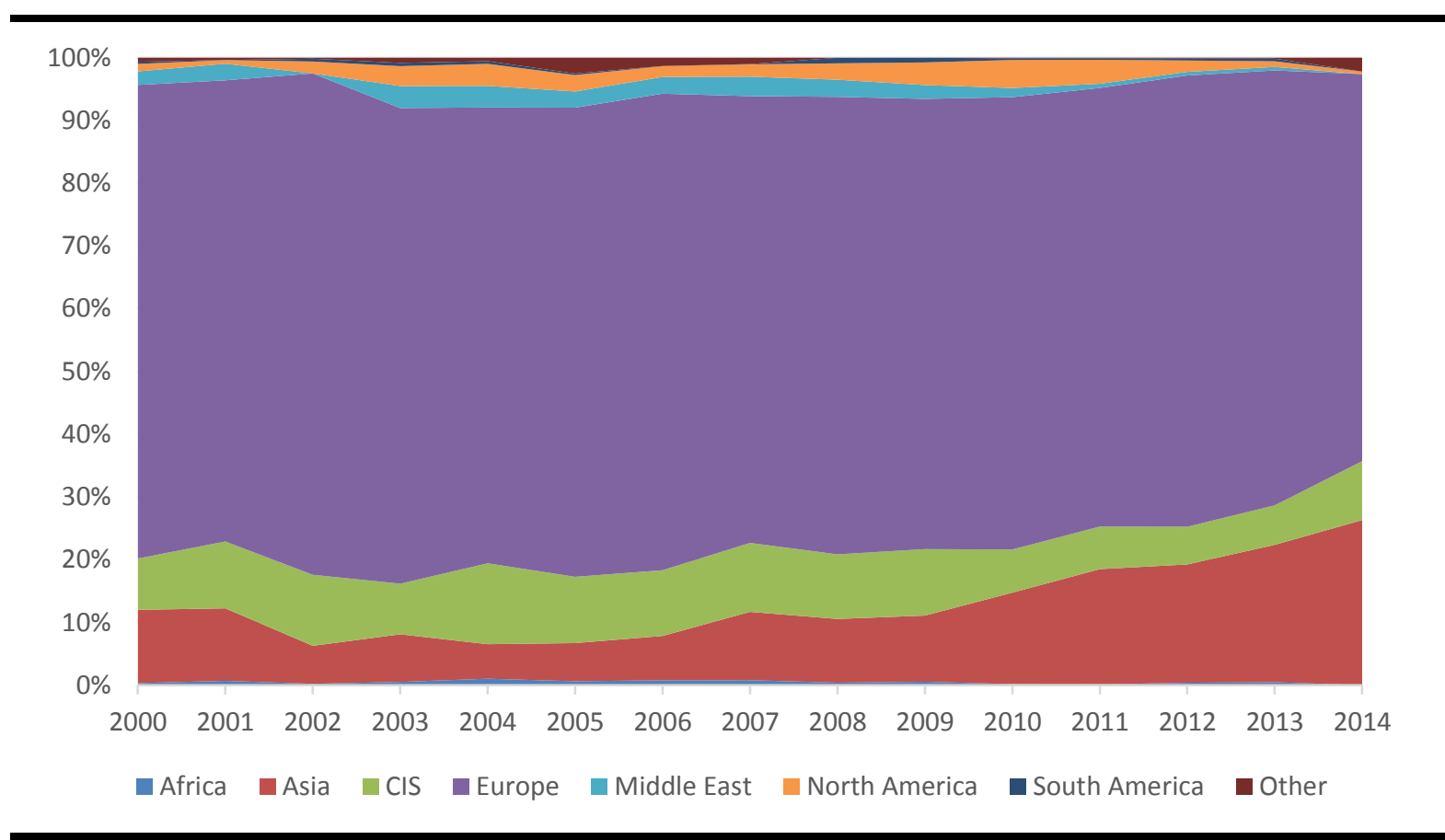

Source: EIA

Figure 3. Russian crude oil exports by destination, by 2014

In natural gas, Russia exported $201.9 \mathrm{bcm}$ (187.4 bcm - pipeline and 14.5 - LNG) in 2014. All PNG (Pipelined Natural Gas) goes to European and FSU countries. Germany, Italy and Turkey are the main customers in European market, which take almost $60 \%$ of total volume of the region. All LNG (Liquefied Natural Gas) exports goes to Asian market, especially to Japan and S. Korea. They import $11.5 \mathrm{bcm}$ and $2.6 \mathrm{bcm}$ of Russian LNG, which take $79.4 \%$ and $17.9 \%$ of regional total.

According to BP, overall Russian natural gas exports show $-10.74 \%$ growth rate in 2014. LNG exports have increased little from $14.2 \mathrm{bcm}$ in 2013 to $14.5 \mathrm{bcm}$, but pipeline exports have decreased a lot from $212 \mathrm{bcm}$ to $187.4 \mathrm{bcm}$ in the same period. This minus growth is due to declined consumption in Europe and Ukraine. Since 2 times of gas crises between Russia and Ukraine, necessity of reducing gas dependency on Russia has emerged in Europe. Recently, both regions are reducing gas consumption and seeking to ease reliance on Russia as relations soured over its annexation of Crimea and the conflict in eastern Ukraine. ${ }^{*}$

In addition to these backgrounds, European environmental policy regarding to $\mathrm{CO} 2$ emission could give negative effects on Russian gas exports to European market. If EU apply strict carbon policy, by 2050, European natural gas consumption could be reduced by $1 / 3$ of current level and Russian exports to Europe could be shrunk by half. ${ }^{\dagger}$ Of course, EU's practical plans for reducing dependency, such as developing gas supply chains in the region; developing shale gas mining fields; constructing substitute gas pipelines from Middle East, Central Asia and Africa; and importing American shale gas, need time to be in action and that plans' effectiveness still seems unclear. ${ }^{\ddagger}$ However, one thing is clear that it's time for Russia to prepare substitute markets, which compensate losses in its cash-cow-market trying to escape from it. On this circumstance, Russia

\footnotetext{
${ }^{*}$ Bloomberg, Russia 2014 Gas Export Seen Lowest in Decade as Demand Falls, http://www.bloomberg. com/news/articles/2015-01-13/russia-2014-gas-exports-seen-lowest-in-decade-as-nations-cut-use

${ }^{\dagger}$ Sergey Paltsev, Scenarios for Russia's natural gas exports to 2050, Energy Economics, vol. 42, pp. 266-267.

${ }^{*}$ Daesik Lee, The Limit and Possibility of EU's Policy of Independence from Russia's Natural gas, Slavic Studies, Vol. 30, No. 3, 2015, p. 166
} 
has plans to build LNG production and transport system, and connect them to Unified Gas Supply System (UGSS). Now Russia has a single operating LNG export facility, Sakhalin LNG, which has been operating since 2009 with an original design facility of 9.6 million tons of LNG per year.* Except this, many LNG facility projects have launched with modification of Law on Gas Export breaking Gazprom's monopoly on gas exports. The main purpose of these facilities will be to strengthen Russia's position in the external market. ${ }^{\dagger}$ We can figure out Russia's intention to expand gas exports to Asian market in its LNG facility plan. Among 9 planned LNG projects 4 are located on the Pacific coast including Sakhalin LNG, which has been operating since 2009 and sole operating LNG liquefaction facility of Russia. Vladivostok LNGand Far East LNG facilities are planned to build 2018 with 15 and 5mtons/year capacity each. In addition, to this expansion project for Sakhalin LNG is expected to start post 2018 and then the facility's annual capacity will rise to 14.6 mtons.There is only 1 LNG facility planning on western side, Baltic LNG facility. Russian energy authority prospects its gas production in Eastern Siberia and Far East will growth by $15 \%$ of total in 2035 and exports to Asia-Pacific region will rise by $42-44 \%$ of total. ${ }^{*}$
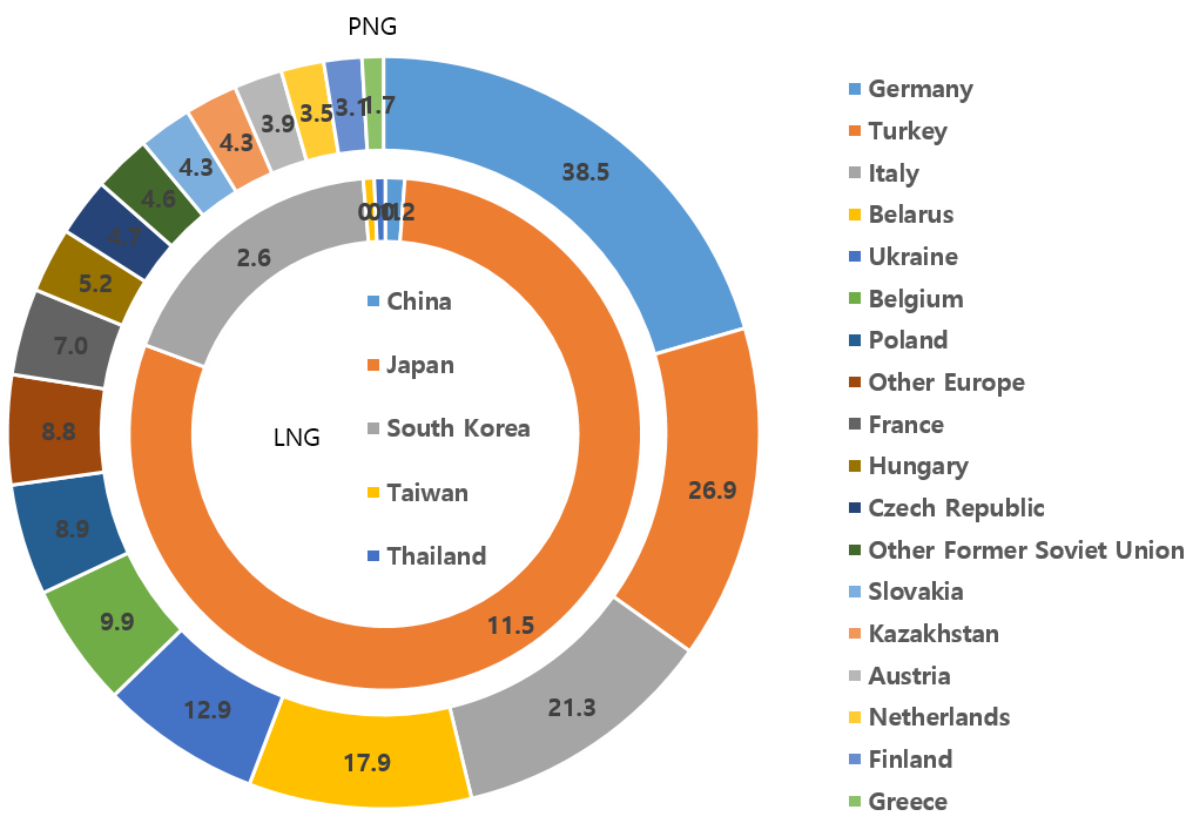

Source : BP statistical review of world energy 2015

Figure 4. Russian natural gas exports by type and destination, 2014, bcm

Changes of oil and gas imports-consumption structure in S. Korea, Japan and China

\section{Changes in oil imports and consumption}

S. Korea's oil supply absolutely depends on imported oil. In 2014, it imports 927 million barrels of crude oil from 29 countries and 329 million barrels of oil products from 49 countries in the world. Japan has a similar situation to S. Korea. It also has no oil in its territory and most of its domestic oil demands are compensated by imported oil. In 2014, it imported about 1.2 billion barrels of crude oil from 25 countries in the world. China became a net oil importer since 1993 due to rapid industrialization, even though its crude oil production has increased gradually since 1985 .

\footnotetext{
* EIA, Country Report: Russia, July 28, 2015, p. 16.

${ }^{+}$Global and Russian Energy outlook to 2040, p. 144.

${ }^{\ddagger}$ Ministry of Energy of Russian Federation, Energy Strategy of Russia for the period up to 2035
} 


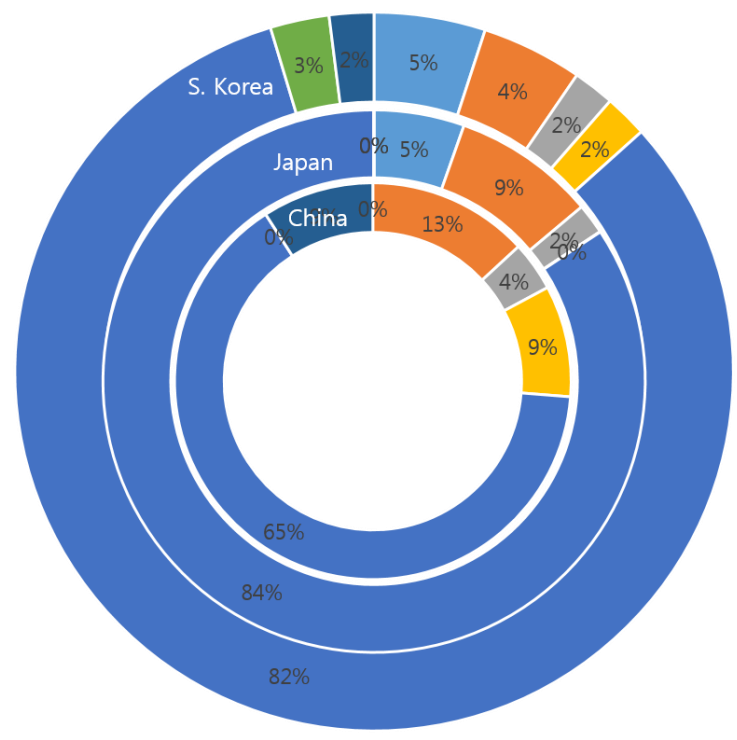

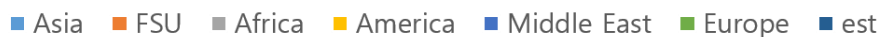

Source: ANRE, KNOC, BP

Figure 5. Crude oil import of S. Korea, Japan and China by origin, 2014

As [Figure 5] shows, S. Korea imports most of its total imported crude oil from Middle East. Middle East takes 82\% of its total oil import. Saudi Arabia is the unchallengeable no.1 supplier for S. Korea. Annually, S. Korea imports average 266 million barrels of crude oil from Saudi Arabia since 2000 and it takes about $32.5 \%$ of S. Korea's total average crude oil import. Kuwait follows as the second with share of $14.7 \%$ of total imports and UAE marks $11.7 \%$. The volume of imported crude oil from these top 3 Middle Eastern countries exceeds 50\% of total oil imports of S. Korea in 2014. This high dependency on Middle Eastern crude oil and on some specific countries has been considered as a potential threaten to energy security of S. Korea and Korean government has sought to diversification of crude oil supply routes since after two times of Oil Shock. This effort for the diversification seemed effective by 1999, however, since 2000, with high price of crude oil in global market, the dependency have started to rise up again and hit the peak in 2011 (87.1\%). Such tendency is because of some reasons, which are reduced exporting capacity of Southeastern countries due to their increasing domestic demands; high transporting cost of American crude oil; increasing market share of Middle Eastern crude oil in global market; nominal policy for diversification of oil importing routes of Korean government. ${ }^{*}$ Like S. Korea, Japan also has high dependency on Middle East in crude oil imports. As [Figure 6] indicates, it imports $84 \%$ of total from Middle East and it is more than 1 billion barrels. Former Soviet Union countries follows with 8.37\% of share (most of it comes from Russia) and Asia marks 5.3\%. In the top 10 suppliers list, 2 Middle East countries, Saudi Arabia and UAE, take first and second position with 369 million and 306 million barrels of oil. Qatar comes next and Russia takes $4^{\text {th }}$ place as sole non-Middle East country in top 5. The different feature of Japan to S. Korea related to the dependency is the tendency. Japan's dependency on Middle East is showing decreasing tendency. Although, it has shown some fluctuations with high dependency rate, overall, it is declining. In 2000, the dependency rate was about $86 \%$ and hit the peak in 2005 as $90 \%$, but in 2014 it maintain the lowest level of dependency on Middle East oil since 2000. China also has the smaller dependency on Middle East in oil imports than that of S. Korea and Japan. In 2014 it marks 64\% and it has maintained over 60\% level since 2008. The Chinese government's current Five-Year Plan targets

\footnotetext{
${ }^{*}$ Dal-seok Lee, Nam-jin Rho, Won-chul Yoon, Chul-gyu Lee, Study on future strategy of petroleum industry,
} Korea Energy Economics Institute, 2010, p. 4. 
oil imports reaching no more than $61 \%$ of its demand by the end of 2015 . China's dependence on crude oil imports in the longer-term will be determined by the sustainability and growth of domestic oil production; the rate of oil consumption growth as the government aims to create more sustainable economic growth; the speed of strategic and commercial stock fill; the fuel efficiency gains in transportation and any substitution of fuels such as natural gas for oil. ${ }^{*}$ It's biggest source in oil imports is Saudi Arabia and Angola. These 2 countries take almost 30\% of total import. Russia comes as $3^{\text {rd }}$ with outstanding growing numbers. Its share in Chinese crude oil imports was $2.10 \%$ in 2000 , but it has shown $7.46 \%$ of annual growth rate on average in the total.

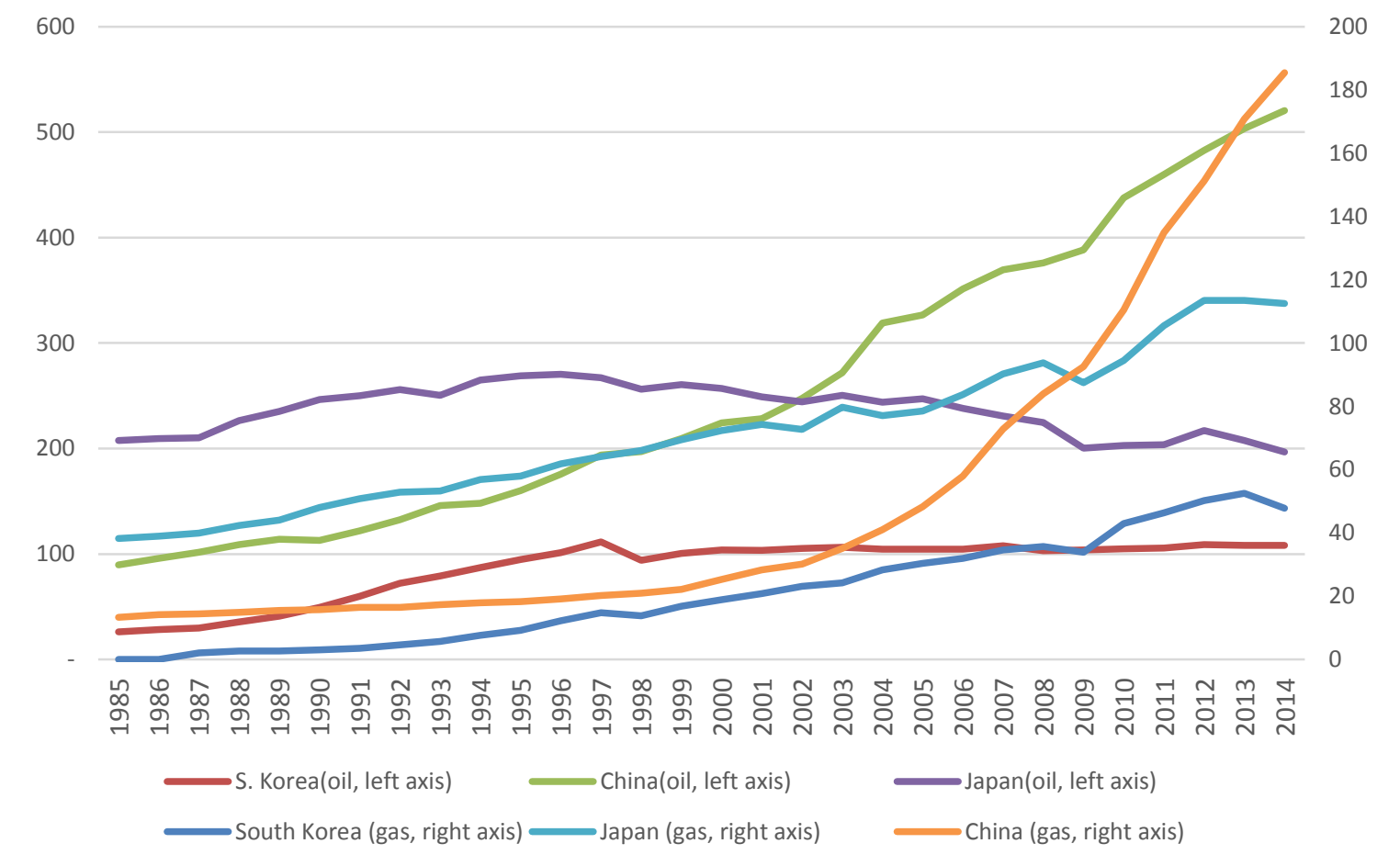

Source : BP statistical review of world energy 2015

Figure 6. Oil and Natural gas consumption of NEA countries since 1985, million tones (left axis), bcm (right axis)

In oil consumption, NEA countries show different tendency. Korean consumption has been growing slowly since 2000, Japanese consumption has been decreasing down since middle of 1990's. Long-term forecast for oil consumption of these 2 countries reflects current tendency. Korean consumption is expected to show $-0.11 \%$ of annual growth rate in average by 2035 in final energy consumption. ${ }^{\dagger}$ Korean government figured out that the minus growth rate in oil consumption mainly due to expected slowdown in economic growth and in population growth. Japan's oil consumption is also expected to mark -0.6\% of annual growth in average by 2040 in final energy consumption ${ }^{*}$ due to the same reasons of S. Korea and development of energy

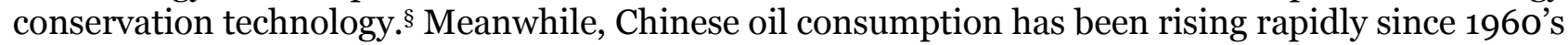
and the velocity of growth in oil consumption has been accelerated as its fast economic growth. Chinese consumption is estimated to grow $2.6 \%$ annually by 2040 , which is higher than 2 times of world average.

\footnotetext{
${ }^{*}$ EIA, Country Overview: China, May 14, 2015, p. 10.

${ }^{\dagger}$ Ministry of Trade, Industry and Energy of Korea, $2^{\text {nd }}$ National Energy Master Plan, 2014, p. 36.

* EIA, International Energy Outlook 2014, 2014, p. 25.
}

\& Agency for Natural Resources and Energy of Japan, Energy White Book 2005, http://www.enecho.meti.go.jp/about/whitepaper/2005html/1-1-1.html 


\section{Changes in natural gas imports and consumption}

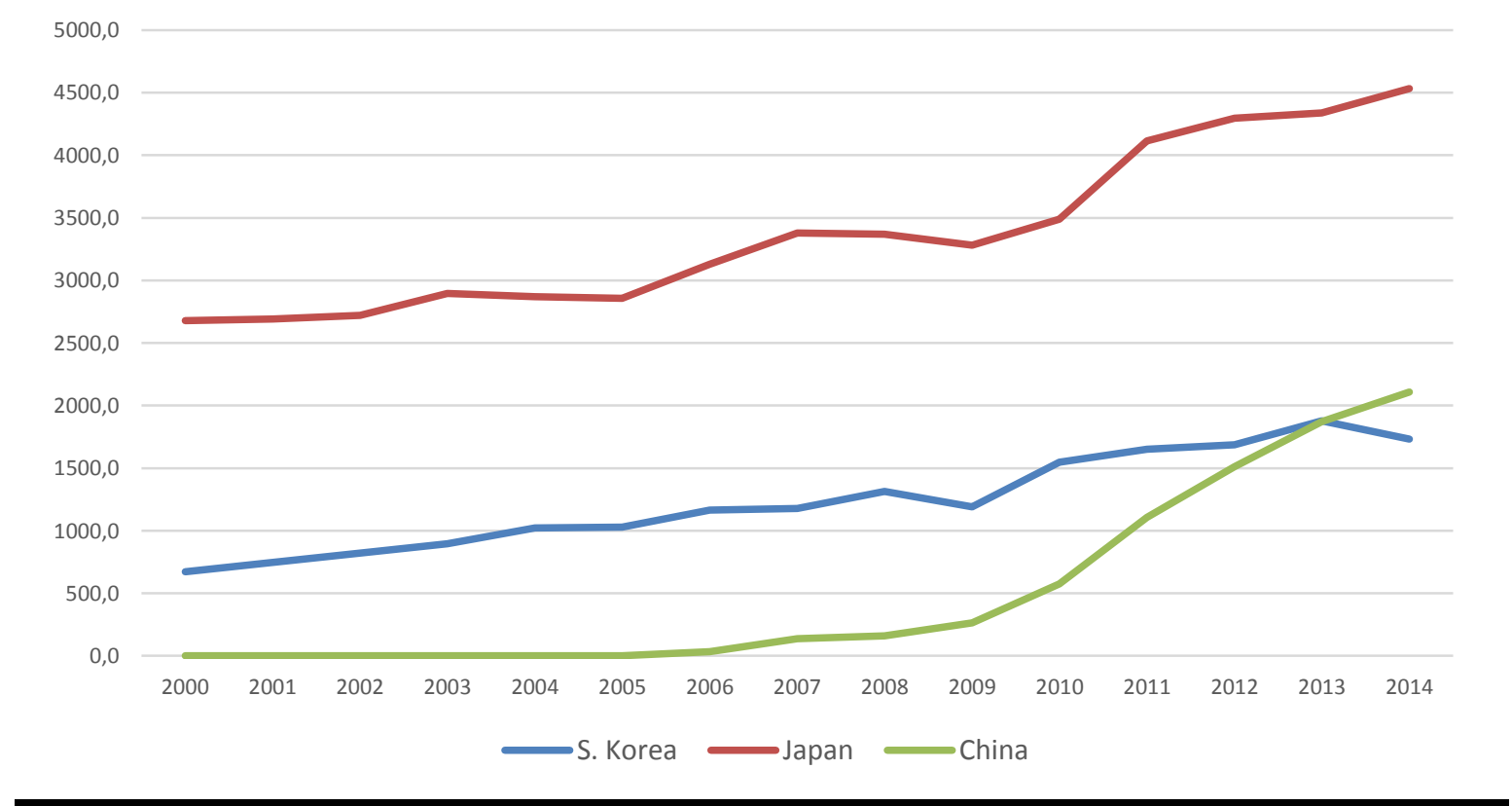

Source : IEA, BP

Figure 7. Natural gas imports of S. Korea, Japan and China since 2000, bcf

S. Korea, Japan and China are the three major importers in global natural gas market. The volume of these countries' gas imports take $23.08 \%$ of world total and $76.6 \%$ of Asia-Pacific total in $2014^{*}$. Comparing to their size of economy and total energy consumption, China imports natural gas relatively smaller than S. Korea and Japan. This is due to China's low gasification level. In total primary energy consumption of China, natural gas takes $4.7 \%$, while it reaches $13.7 \%$ and $11.2 \%$ in S. Korea and Japan. China needs to increase share of oil and natural gas in its energy supply and consumption structure reducing dependency on coal. Actually, coal takes $67 \%$ of TPES and 37\% of TFEC of China in 2013. China has been showing overwhelmingly higher growth rate of gas imports than S. Korea and Japan since 2009 as [figure 7] illustrates. By 2005, China didn't import natural gas, but since it started to import $322 \mathrm{bcm}$ of gas in 2006, it shows $85.5 \%$ of annual growth rate in average by 2014 and caught up S. Korea in 2013. In the same period, natural gas imports of S, Korea and Japan also have increased gradually.

In terms of diversity, these 3 countries have more diversified importing routes than their crude oil importing routes. In 2014, S. Korea imports approximately $27.2 \mathrm{bcm}$ of natural gas from Middle East in forms of LNG, which takes 53\% of total gas imports. The major sources of gas imports for the country are Qatar, Indonesia, Oman and Malaysia. Russian gas is imported $2.6 \mathrm{bcm}$ in the year. Unlike S. Korea, Japan has higher share of Asia-Pacific region in natural gas imports. Australia is the biggest supplier for Japan (25 bcm), Qatar (21.9 bcm), Malaysia (20.3) and Russia (11.5) follow. China imports almost half of total gas imports from FSU countries, especially from Turkmenistan $(25.5 \mathrm{bcm})$. Qatar $(9.2 \mathrm{bcm})$ and Nigeria $(5.2 \mathrm{bcm})$ come next. At regional level, these countries have similar degree of dependency in gas imports, but on different regions each other. However, at the level of exporting countries, Japan show much higher diversity than that of S. Korea and China. Japan imports natural gas from 14 countries and the top supplier, Australia, takes just $21 \%$ of total share. It is relatively lower than others'. S. Korea's top supplier, Qatar, takes $35 \%$ and China's one, Turkmenistan, has $44 \%$ of total share. In addition to this, gaps between top supplier and second supplier is smaller in Japanese imports chart than in others. Gap between Australia, the top supplier for Japan, and Qatar, second supplier, is $3.09 \mathrm{bcm}$, but this gaps in S. Korea's and China's chart are shown $10.57 \mathrm{bcm}$ and $16.33 \mathrm{bcm}$ each. Japanese portfolio in natural 
gas imports could be more diversified after 2017 when it begins to import American shale gas, which takes approximately $20 \%$ of annual natural gas imports of Japan.*

In natural gas consumption, NEA countries have totally different situation. S. Korea and Japan have recorded gradually growing consumption curve. Japan is world $5^{\text {th }}$ in natural gas consumption (112.5 bcm in 2014) and S. Korea consumes $47.8 \mathrm{bcm}$ of natural gas in a year. Overall, S. Korea's gas consumption shows increasing tendency. It didn't consume natural gas at all by 1985 and gradually has increased consuming volume. Despite of stable growth of S. Korea and Japan in gas consumption, forecasts for their future consumption are pessimistic. Japanese gas consumption is expected to fall gradually due to the same reasons of oil consumption fall according to Japanese government and government's plan to reactivate its nuclear power facilities, which was fully frozen since Fukushima crisis. S. Korea's gas consumption is expected to show $0.1 \%$ of average fall by 2027 comparing to 2012 according to "11 $1^{\text {th }}$ Long-term Natural Gas Supply Plan (2013$2027)^{\dagger \prime}$. Chinese gas consumption has been growing rapidly since 2000, when its growth rate marked 14\%. In 2014, it consumed more 10 times of gas than the volume in 1995 and its volume of gas consumption caught up Japan in 2009. Total volume of Chinese gas consumption will grow in long-term range due to Chinese government anticipates boosting the share of natural gas as part of total energy consumption to at least $10 \%$ by 2020 to alleviate high levels of pollution resulting from the country's heavy coal use. ${ }^{\ddagger}$ However, growth rate is predicted to slow down in midterm despite of the government's coal-consumption control policy. IEA forecasts that Chinese gas consumption will mark $314 \mathrm{bcm}$ in 2020 and growth rate will be 8-9\%, which is smaller than past. ${ }^{\S}$ Meanwhile, National Development and Reform Commission (NRDC) of China adjusted downward its forecast of China's gas consumption in 2020 from $400 \mathrm{bcm}$ to $360 \mathrm{bcm}$. China National Petroleum Corporation released more pessimistic projection, which predicts $300 \mathrm{bcm}$ in $2020 .{ }^{* * *}$ This is due to slowing down of economic growth, relatively higher price of gas and expanding demand of nonfossil energy resource in Chinese market.

\section{Res production and consumption in NEA countries}

\section{Production of RES}

NEA countries are applying diverse policies for developing the sources and technologies. As we see in [figure 12] overall renewable output in the countries shows rising tendency except Russia. The absolute volume of Chinese renewable production overwhelms other countries, 239 mtoe in 2013, however, its share in TPES have been decreasing since 2002, when it took $16 \%$ of share in TPES. In 2013, the share has been cut into the half of 2002, 8\% of TPES. This is because while TPES has grown 140\% since 2002 to 2013, renewable production has increased just $16 \%$. S. Korea records remarkable growth rate in renewable, which was $10 \%$ in 2013 and $11 \%$ in average for the last decade, although still it has small producing volume and share in TPES. While TPES has risen $33 \%$, renewable production has grown 203\% in the period. Despite of this outstanding growth in production, renewable energy takes less than $2 \%$ of TPES in S. Korea. On the other hand, Russia is stuck showing fluctuation of production in the range of around 10 mtoe. Russia has shown average $2 \%$ of growth rate since 2002 and in Russia renewable energy production takes $1.06 \%$ of TPES, which is the lowest level among the countries. Its share in TPES was 1.13\% in 2002, but it has decreased to $1.06 \%$ in 2013 . While its TPES has grown $17 \%$ for last 10 years, renewable production has increased $10 \%$, which is lowest level among the 4 countries. This is a quite disappointing result for Russia considering its huge potential in renewable energy source and policy efforts to the sector. Since 2007, Russia has developed a comprehensive political and regulatory framework for renewables in the wholesale and retail markets. However actual deployment have been very slow

\footnotetext{
*日経ビジネスオンライン, 米国発のシェール革命の波を日本へーー新たな天然資源が秘める可能性, http://special.nikkeibp.co.jp/as/201401/sumitomocorp/vol1_page1.html

${ }^{\dagger}$ Ministry of Trade, Industry and Energy of Korea, 11th Long-term Natural Gas Supply Plan (2013-2027), 2013.

* EIA, Country Report: China, Updated May 14, 2015.

$\S$ IEA

** Kwang-Soo Hwang, Slowing down of Chinese growth rate in natural gas-consumption and its influence, Quaterly Review of Center for Gas Economics \& Management, 2015, vol. 14, no. 1, p. 18.
} 
due to the large availability and share of fossil fuels used for heat and power generation, the concern about avoiding higher end-user electricity prices, and challenges from how to integrate renewables in the electricity system. ${ }^{*}$ Japan have achieved about $4 \%$ of average annual growth rate in renewable production for last 10 years. Its renewable production had increased by 2007 and marked minus growth in 2008 and 2009. Since 2010 Japan has shown about $11 \%$ of growth rate by 2013. Japanese ratio of RES to TPES was $1.86 \%$ in 2002 and it has risen by $3.05 \%$ in 2013. This growth rate in renewable production partly due to Japanese decreasing TPES. Since 2004, Japanese TPES has declined year by year. It was 510.54 mtoe in 2002 and through fluctuated pattern by 2005 it recorded 454.66 mtoe in $2013,-11 \%$ comparing to 2002 . As already mentioned, this is related to depressed socio-economic condition of Japan. Japan is the only one country showing declining TPES among NEA countries and it is expected to be continued in the future ${ }^{\dagger}$.

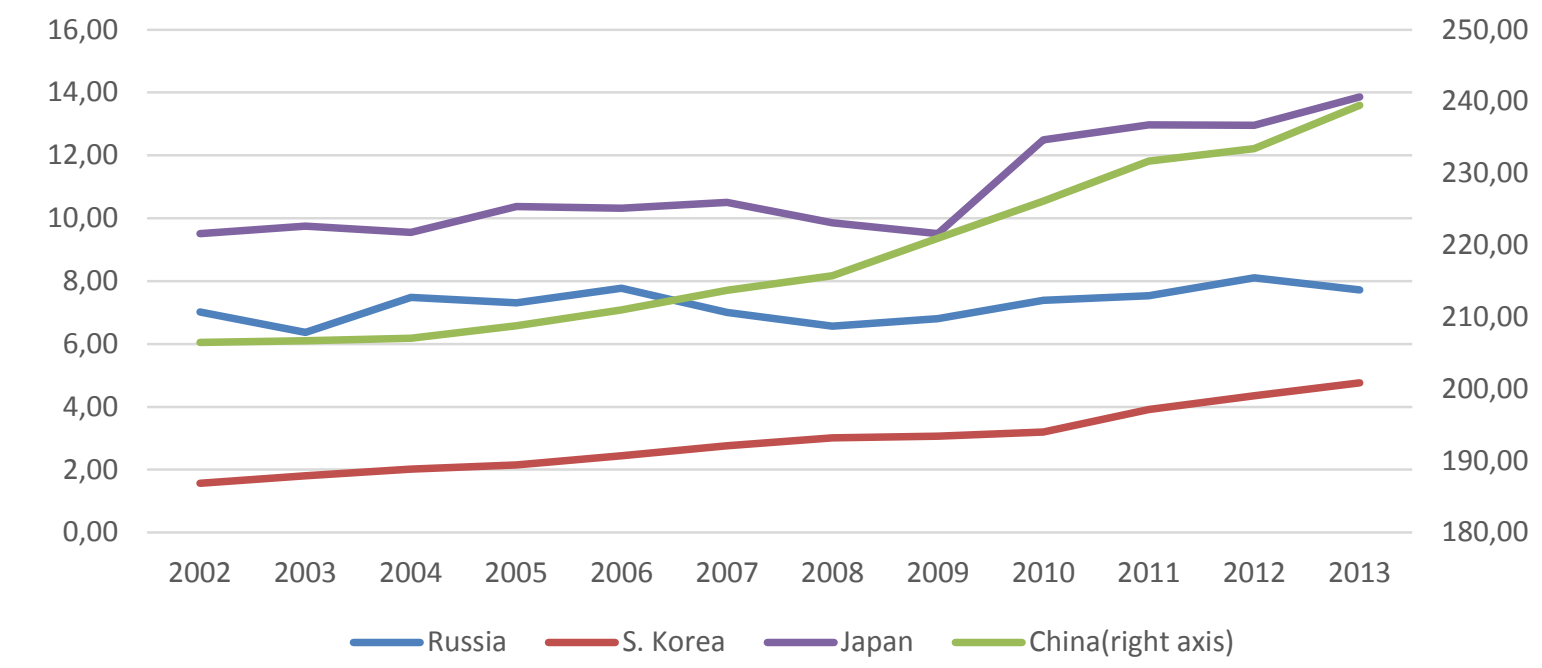

Source : IEA, Energy Statistics of OECD countries 2014, Energy Statistics of non-OECD countries 2014

* Converted to mtoe from original unit (TJ)

Figure 8. Changes in generation and production of renewables, mtoe

The structure of renewable energy production of the countries shows quite different features. S. Korea has relatively well balanced producing structure by sources. As we see in [table 3], S. Korea use every renewable sources for production energy. Industrial wastes take $48 \%$ of total renewable energy production by sources. Solid biofuels and municipal wastes follow. In electricity generation, S. Korea has the most diversified portfolio among the countries, the most diverse sources (8 types) are used. Japan also shows quite diversified structure in both renewable production and generation. Unlike S. Korea, Japan's dominant renewable source in production is solid-biofuels taking $61 \%$ of total, after that geothermal and industrial waste follow. Municipal waste and solar thermal also has share as renewable source marking $9 \%$ and $2 \%$ share. In electricity generation by renewables, Japan show the lowest dependency level on hydropower, $57.49 \%$ of total. Solid fuels takes second place, $21.7 \%$ of total, after that solar PV, municipal waste, wind, geothermal and industrial waste follow with one digit share of total.

Meanwhile, Russia has the most biased structure in both renewable production and electricity generation by renewables. In production of renewables, just 2 sources, industrial waste and solid biofuels, take more than $94 \%$ of total share. In electricity generation, we can see huge dependency on hydropower taking more than $98 \%$ of total generation by renewables. In other words, Russia quite depends on relatively traditional and low-technology renewable sources. China has a better structure in both production and generation than that of Russia. In $2013,84 \%$ of

\footnotetext{
${ }^{*}$ IEA, Energy policies beyond IEA countries: Russia 2014, OECD/IEA 2014, p. 219.

${ }^{\dagger}$ Energy White Book of Japan 2014
} 
Chinese renewable energy production comes from primary solid biofuels and $81 \%$ of renewable electricity generation is produced by hydropower. A different feature from Russia is that Chinese structure in renewable production and generation has been developing by year in terms of sourcediversity. In electricity generation, geothermal and ocean power has begun to be used in 2005, after that electricity production by using industrial waste and solar thermal has started in 2010 and 2011. In renewable production also, China has added liquid biofuels and industrial waste into its renewable source portfolio in 2006 and 2010. These added renewable sources has been increasing steadily their absolute volume and share in totals. In short, China has quite similar problems to Russia in renewable energy supply, dependency on some specific sources, but it has been improving its structure steadily.

Table 3: Renewable energy production and electricity generation by renewables by source, 2013 , \% of total

\begin{tabular}{|c|c|c|c|c|c|c|c|c|}
\hline \multirow[t]{2}{*}{ Country } & \multicolumn{2}{|l|}{ Russia } & \multicolumn{2}{|l|}{ S. Korea } & \multicolumn{2}{|l|}{ China } & \multicolumn{2}{|l|}{ Japan } \\
\hline & Product. & Gen. & Product. & Gen. & Product. & Gen. & Product. & Gen. \\
\hline $\begin{array}{l}\text { Municipal } \\
\text { waste }\end{array}$ & - & - & $18.23 \%$ & $2.74 \%$ & - & - & $9.23 \%$ & $4.18 \%$ \\
\hline $\begin{array}{l}\text { Industrial } \\
\text { waste }\end{array}$ & $54.93 \%$ & $1.55 \%$ & 48.11\% & $2.14 \%$ & $2.20 \%$ & $1.09 \%$ & $10.10 \%$ & $1.63 \%$ \\
\hline $\begin{array}{l}\text { Primary } \\
\text { solid } \\
\text { biofuels }\end{array}$ & $39.23 \%$ & $0.02 \%$ & $20.00 \%$ & $3.73 \%$ & 83.91\% & $3.40 \%$ & $61.02 \%$ & $21.75 \%$ \\
\hline Biogases & - & - & $4.97 \%$ & $4.55 \%$ & $3.28 \%$ & - & - & - \\
\hline $\begin{array}{l}\text { Liquid } \\
\text { biofuels }\end{array}$ & - & - & $6.28 \%$ & $0.00 \%$ & $0.90 \%$ & - & - & - \\
\hline Geothermal & $5.84 \%$ & $0.24 \%$ & $1.83 \%$ & - & $1.88 \%$ & $0.01 \%$ & $17.36 \%$ & $1.76 \%$ \\
\hline $\begin{array}{l}\text { Solar } \\
\text { thermal }\end{array}$ & - & - & $0.58 \%$ & - & $7.82 \%$ & - & $2.28 \%$ & $0.00 \%$ \\
\hline Hydro & - & 98.19\% & - & 62.67\% & - & $81.61 \%$ & - & $57.49 \%$ \\
\hline Solar PV & - & - & - & $11.98 \%$ & - & $1.37 \%$ & - & $9.67 \%$ \\
\hline $\begin{array}{l}\text { Tide, wave, } \\
\text { ocean }\end{array}$ & - & - & - & $3.61 \%$ & - & - & - & - \\
\hline Wind & - & - & - & $8.58 \%$ & - & $12.52 \%$ & - & $3.52 \%$ \\
\hline
\end{tabular}

Source : IEA

\section{RES Consumption}

The tendency of each NEA countries' overall consumption in renewable energy sources combining transformation and final consumption follows production of renewable energy. Except Russia, which seems be stuck in the level of 7 mtoe, S. Korea, China and Japan have been showing rising tendency since early 2000's at the different level. Among them, S. Korea records 10.5\% of average growth rate since 2002 and consumes 4.8 mtoe of renewable energy in 2013. This average growth rate overcomes world average (9.02\%) in the same period and almost 10 times bigger than growth rate of Russia. Japan has the second place among NEA countries in terms of growth rate of RES consumption. The rate increases $7.1 \%$ in 2013 and records 3.9\% of average growth rate for the last decade. China and Russia records $1.4 \%$ and $1.1 \%$ of growth rate in the same period, but a difference between them is that China is on the rising tendency in RES consumption since 2006, but Russia has been stagnant at around early 7 mtoe since 2004 with fluctuating tendency.

In consumption by sector NEA countries show very different tendency and mix. Russian renewable energies are consumed in relatively diverse sectors considering its biased production structure. The biggest sector is transformation, in which included electricity, heat and CHP plants. Transformation sector takes $65 \%$ in 2013 and has maintain that volume of share for ten years. This dominant share of transformation sector is expected at least to stay at that level or to grow as Russia's long-term energy strategy planed. In the 'Energy strategy of Russia for the period up to 2030', expanding renewable energy sources in the electric energy and heat production is stressed 
with specific target number for the first time in its history of official publication on national energy strategy. Residential purpose use has 16\% share of total in 2013 and its proportion has decreased steadily from $25 \%$ in 2002.
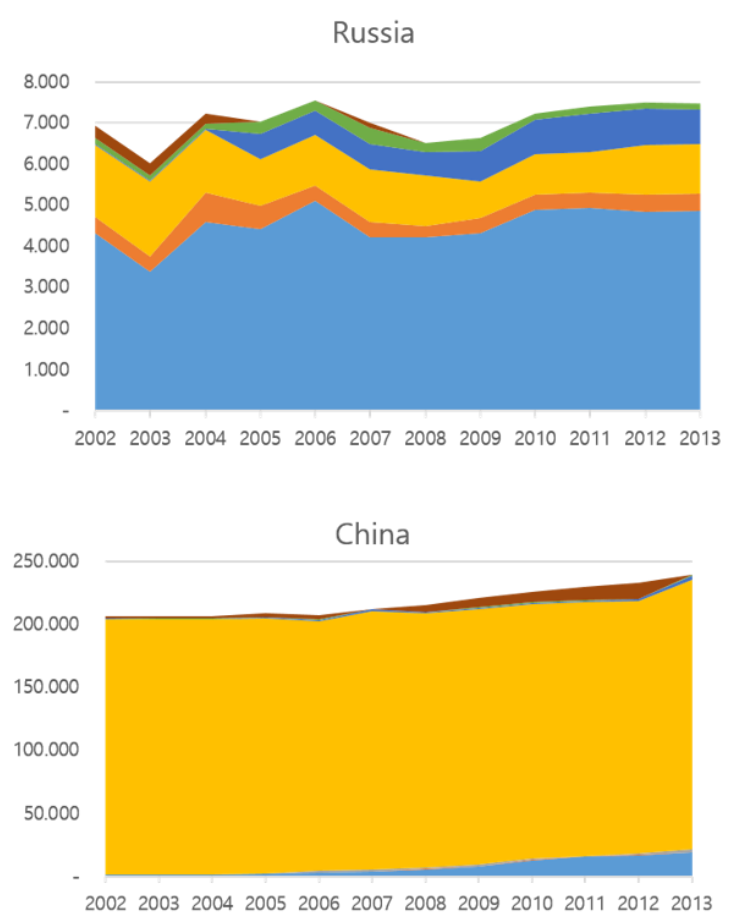

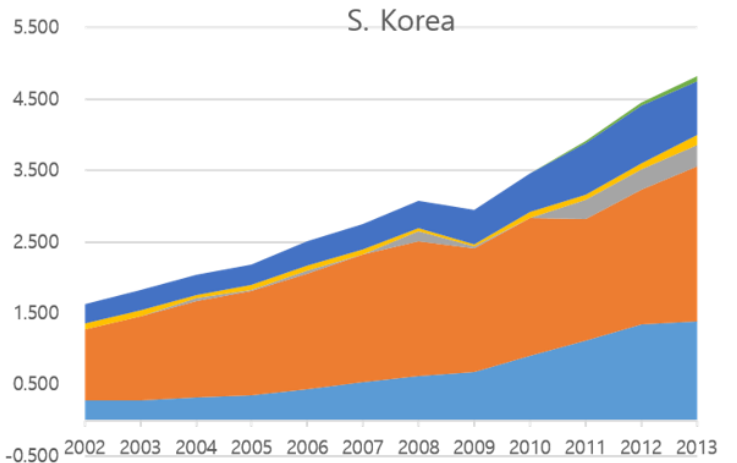

$-0.50020022003200420052006200720082009201020112012 \quad 2013$

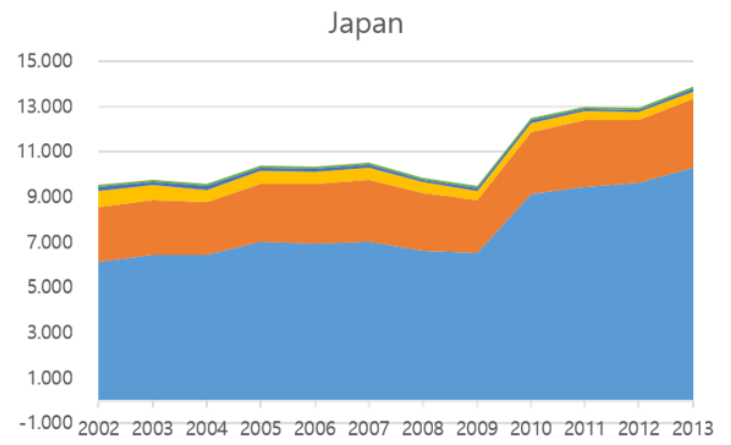

- Transport

- Agriculture / forestry

- Non-energy use

n of which chemical / petrochemical

Source : IEA, Energy Statistics of OECD countries 2014, Energy Statistics of non-OECD countries 2014

* Converted to mtoe from original unit (TJ)

Figure 9. RES consumption by sector, mtoe

Meanwhile, Chinese overwhelmingly higher share of residential sector in renewable partly represents its higher share of hydropower and solid biofuels in production. Its share of total renewable consumption was over $98 \%$ in 2002, but since that year it has been declined to $89 \%$ and other sectors have increased their share due to Chinese governmental policy efforts improving regulation on renewable sector and stimulating investment into the sector. ${ }^{*}$ Unlike Russia and China, significant volume of renewable energies of S. Korea is consumed in industrial sector, rather than transformed into electricity and heat. However, the share of industry sector in RES consumption has been decreasing from $60 \%$ in 2002 to $45 \%$ in 2013. As share of industry sector has decreased, shares of transformation sector and transport sector have been rising each from $17 \%$ and $0.05 \%$ in 2002 to $28 \%$ and $3 \%$ in 2013 . Interestingly, S. Korea is the sole country, in which the final consumption sector is bigger than primary consumption, transformation. This is related to development of solid and liquid biofuels. Japan's dominant sector in renewable consumption is transformation as like Russia. Its share in total renewable consumption was $64 \%$ in 2002 and has risen by $74 \%$ in 2013. The second and the biggest sector in final consumption is industrial sector

\footnotetext{
* For details see:Seung-chan Park, study on Xi Jinping government's long-term development strategy of renewable energy, China and sinology, vol. 21, 2014, pp. 197-213.
} 
that takes 22\% of total in 2013 and has declined from 25\% in 2002 as transformation sector has increased. Development of renewable energy sources including supply and demand side is affected by governmental policies more than other traditional energy sources. All NEA countries' government established its own national renewable energy plans and we can find out the countries target with specific numbers.

Limited motivation for building cooperation through conventional energy sources and role of RES

As we saw NEA countries' energy status in previous chapter, Russia, S. Korea, Japan and China have different features to each other in supply and demand of current major energy sources, crude oil and natural gas, and future energy source, renewables. As the conclusion of our work, in this chapter, we summarize the discordances of the countries' needs in supply and consumption structure of the energy sources from the viewpoint of building energy cooperation.

Firstly, we can observe potential discordance of needs in energy cooperation between Russia and other NEA countries. As we reviewed, it's clear that there will be no surprisingly high growth rates in oil production and even it could be reduced in near future. Natural gas production is expected to rise and Russia has enough reserve, but it could be reduced by recent changes in global energy market.On the other hand, consumption in oil and natural gas of Korea and Japan will decrease due to their socio-economic conditions. However, their high dependency on Middle East in oil imports makes them have attraction to Russian crude oil. Unlike oil imports, these two countries already have quite diversified importing routes in natural gas. Considering decreasing gas consumption forecast and diversified importing routes in these two countries, needs in Russian gas could be not so much strong in Korea and Japan in near future. Meanwhile, China already has enough share of Russian oil in its imported oil portfolio, but has necessity for Russian natural gas in order to increase share of gas in its final consumption. In other words, there could be mismatch between countries' needs in conventional energy sphere for cooperation. Since collapse of USSR, when cooperation between NEA countries and Russia in energy sphere had begun to be discussed, it was an undoubted assumption that the three NEA countries have strong needs in conventional energy resources, oil and gas. It was right at that times when they were on the rising curve of energy consumption. Now S. Korea and Japan already have touched the peak in oil and gas consumption. China seems to be closing to the peak considering its slowing down growth speed in oil and natural gas consumption. Of course, S. Korea, Japan and China will consume huge amount of oil and natural gas, and these two energy sources will be remain as main energy sources in both supply and consumption. However, the matter is that the less they consume these energy sources, the weaker motivation to build energy cooperation they will have. Recent tendency in the countries' oil and gas consumption and in the global energy market seem make the countries lose the motivation, or urgency, for building regional cooperative regime in energy sector. This is negative for all NEA countries, especially for Russia. For the last decade Russia have had strategic advantage in negotiation of bilateral energy projects in the region with high-energy price in the global market and high economic growth in the region. Now the conditions have changed except Russian needs in Asian market. As we saw, Russian oil and gas production very depends on eastern part of the country, but Russia's major market, European market, intend to reduce dependency on Russian energy sources. This is why Russian government consider developing energy-mining fields and expanding to Asian market as the higher priory goal in its long-term energy strategy.In summary, S. Korea and Japan will prefer to Russian oil than natural gas in order to reduce dependency, but the degree of preference could be declined as their total oil consumption is decreased and low global energy price is maintained. China have needs in Russian natural gas rather than in oil, but the degree could be declined as its speed of total gas consumption growth is slow down. On the other hand, Russia's needs in Asian oil and gas market still remain, so these countries changed needs in oil and gas could be negative for Russia's future strategy in Asian market. Therefore, in order to response to these changes for protecting its interests, Russia needs to its strategy in Asian energy market.

Secondly, in these circumstances, renewable energy sources could be a solution, which could compensate lost motivation for energy cooperation in this region. As we checked in previous chapter, four NEA countries have different levels and structures in renewable energy sector. 
Although they all have low share of renewable energy in their total energy supply, S. Korea and Japan are increasing production and electricity generating through renewable sources with enthusiastic governmental policies. China already has world top position in renewable sources in terms of producing volume, but in terms of quality, it is hard to say that China has advanced features in renewable energy sector. Russia is worse than China in terms of quantity and quality of renewable production. However, the common feature shared by the countries is that they are seeking to develop renewable energy sources as a high-priory national agenda. S. Korea aims to takes $11 \%$ of TPES and $13.4 \%$ of total electricity generation from renewable energy sources by $2035^{*}$. During the period from 2014 to 2035, annual average growth rate is expected to mark $6.2 \%$ while TPES rises $0.7 \%$ in the same period. With this policy target, Korean government intends to reduce share of waste in renewable source production and to increase share of solar PV and wind from $2.2 \%$ and $2.7 \%$ in 2014 to $18.2 \%$ and $14.1 \%$ each by 2035 . If these governmental plans are achieved, Solar PV, Sola thermal, wind and geothermal will take major portion in Korean renewable energy production. Japan try to increase share of renewable energy by $10 \%$ in TPES and by $13.5 \%$ in the total electricity generation by 2020 . It could be raised up to $33 \%$ of total generation by 2030 if total generation in the year will remain at the same level of 2013 according to Ministry of Environment of Japan ${ }^{\dagger}$. In order to achieve the goal, Japanese government implemented feed-intariff scheme in 2012 and intends to support wind power and geothermal power ${ }^{\ddagger}$. In this forecast, solar power will take the biggest share in total generation by renewable sources at minimum 2,493 $\mathrm{kwh}$ to maximum $3045 \mathrm{kwh}$. Wind power comes next maximum 1,533 $\mathrm{kwh}$ and small and medium size hydropower follows. In other words, Japanese renewable supply structure will be transformed from hydropower-centric generation structure as we saw above to solar and wind-centric structure. Chinese target share is $11.5 \%$ of TPES by 2015 and it is expected to rise to $16 \%$ by 2030 under the current policies and investment patterns ${ }^{\S}$. In this condition, hydropower will remain as the overwhelmingly dominant source in 2030. Its output will increase by 1,600 twh, while solar PV and solid biomass and gas grow by 650 twh and 200 twh by $2030^{* *}$. According to 'Energy Strategy 2035', Russian renewable target is to increase electricity generation from renewable energy sources at least 10 times than that of 2014. As we already checked, hydropower provides more than $98 \%$ of Russian electricity generation from renewable sources. Excluding hydropower, other renewable sources compensate just $0.32 \%$ of total electricity supply. Therefore, it looks so hard to fulfill this target without huge amount of investment and policy efforts. Comparing to that Japan and S. Korea have begun its first renewable project and policy in early 1980's and China has released a lot of policies and projects on renewables, Russia just has started unified national frameworks on renewable energy sources. Its first policy on renewable sources is addressed in 2003 in 'Energy Strategy 2020', legal framework was established in 2013.

Of course, it is not simple question how to apply renewable energy sources to cooperation between countries and it is over the research range of this article. However, it is clear that regional energy cooperation in conventional energy sources is constrained by weakening motivation and discordance of needs between countries. Recalling the pattern or characteristic of energy cooperation projects between Russia and other NEA countries, competition for Russian energy sources as we saw in case of ESPO and Sakhalin LNG facility, the weakening motivation for energy cooperation from consumption side will be a critical threaten not only for Russia, but also for the cooperation itself. It is undoubted and unchallengeable that enlarging economic sphere by cooperation in energy resources is beneficial for all NEA countries. Therefore, it is necessary to find out stimulating and rebalancing sources for the cooperation. In this context, renewable energy sources that all NEA countries seek to develop, could conduct a role to motivate the cooperative idea.

\footnotetext{
* Ministry of Trade, Industry and Energy of Korea, $4^{\text {th }}$ national new and renewable energy master plan of Korea, 2014.

† Smart Japan, 2030年に再生可能エネルギー33\%へ、原子力にこだわらない環境省の予測 : http://www. itmedia. co.jp/smartjapan/articles/1504/o7/newso33.html (2015.04.07)

₹ For detail, see 'Strategic Energy Plan of Japan, 2014' section 3 in chapter 3

$\S$ International Renewable Energy Agency, Renewable energy prospects: China, 2014, p. 5.

** Ibid.
} 


\section{References:}

Articles

1. Daesik Lee, The Limit and Possibility of EU's Policy of Independence from Russia's Natural gas, Slavic Studies, Vol. 30, No. 3, 2015

2. Dal-seok Lee, Nam-jin Rho, Won-chul Yoon, Chul-gyu Lee, Study on future strategy of petroleum industry, Korea Energy Economics Institute, 2010

3. Kwang-Soo Hwang, Slowing down of Chinese growth rate in natural gas-consumption and its influence, Quaterly Review of Center for Gas Economics \& Management, 2015, vol. 14, no. 1

4. L.V. Eder, L.V. Eder I.V. Filimonova , V.YU. Nemov, I. A. Provornyy, Production, processing and export of oil and oil products in Russia, Bulletin of the Tyumen State University. 2014. № 4. Earth sciences

5. Nobuyuki Higashi, Natural gas in China: Market evolution and strategy, IEA, 2009

6. Omar Ellabban, Haitham Abu-Rub, FredeBlaabjerg, Renewable energy resources: Current status, future prospects and their enabling technology, Renewable and Sustainable Energy Reviews, vol. 39, 2014 vol. 42

7. Sergey Paltsev, Scenarios for Russia's natural gas exports to 2050, Energy Economics,

8. Seung-chan Park, study on Xi Jinping government's long-term development strategy of renewable energy, China and sinology, vol. 21, 2014

9. WojciechKononczuk, Russia's Best Ally: The situation of the Russian oil sector and forecast its future, OSW Studies, no. 39, 2012

\section{Official documents}

10. Agency for Natural Resources and Energy of Japan, Energy White Book 2005

11. http://www.enecho.meti.go.jp/about/whitepaper/2005html/1-1-1.html

12. $\_$Energy White Book 2015

13. EIA, Country Overview: China, May 14, 2015

14. _ Country Report: Russia, July 28, 2015

15. _ International Energy Outlook 2014, 2014

16. Ministry of Trade, Industry and Energy of Korea, 11th Long-term Natural Gas Supply Plan (2013-2027), 2013

17. — $2^{\text {nd }}$ National Energy Master Plan, 2014, p. 36

18. $\longrightarrow 4^{\text {th }}$ national new and renewable energy master plan of Korea, 2014

19. Ministry of Energy of Russian Federation, Energy Strategy of Russia for the period up to 2030, 2010

20. —_ Energy Strategy of Russia for the period up to 2035, 2015

21. Agency for Natural Resources and Energy of Japan, Energy White Book of Japan, 2015

22. $\quad$ Strategic Energy Plan of Japan, 2014

23. IEA, Energy policies beyond IEA countries: Russia 2014, OECD/IEA, 2014

24. International Renewable Energy Agency, Renewable energy prospects: China, 2014

25. Korea Energy Economics Institute, Energy consumption Survey 2014.

26. The Energy Research Institute of the Russian Academy of Science, Analytical Centre of the Government of Russian Federation, Global and Russian Energy outlook to 2040, 2014

Data \& online sources

27. British Petroleum, BP Statistical review 2015, 2015

28. IEA, Energy Statistics of OECD countries, OECD/IEA, 2014

29. _ Energy Statistics of non-OECD countries, OECD/IEA, 2014

30. Bloomberg, Russia 2014 Gas Export Seen Lowest in Decade as Demand Falls, http://www.bloomberg.com/news/articles/2015-01-13/russia-2014-gas-exports-seen-lowest-indecade-as-nations-cut-use

31. Japan petrochemical Industry Association: http://www.jpca.or.jp/chek/4stat/ ooindex.htm\#3Y -02.html

32. Korea Petrochemical Industry Association: http://www.kpia.or.kr/pcind/ pcind_o4

33. Statistical bureau of China, http://www.stats.gov.cn/tjsj/ndsj /2014/zk/html 
/Zo206C.htm

34. Statistical Bureau of Korea, http://www.index.go.kr/potal/main/PotalMain.do

35. Smart Japan, 2030年に再生可能エネルギー33\%へ、原子力にこだわらない 環境省の予測：：http://www.itmedia.co.jp/smartjapan/articles/1504/o7/newso33.html (2015.04.07)

36. The Observatory of Economic Complexity, http://atlas.media.mit.edu/en/

37. US Department of Energy, The Transportation Energy Data Book edition 34, 2015, http://cta.ornl.gov/data/index.shtml

38. 日経ビジネスオンライン，米国発のシェール革命の波を日本へ－ー新たな天然資 源が秘める可能性, http://special.nikkeibp.co.jp/as/201401/sumitomocorp /vol1_page1.html

УДК 33

\title{
Энергетическое партнерство России и стран Северо-Восточной Азии
}

\author{
${ }^{1}$ Сергей Михайлович Никоноров \\ ${ }^{2}$ Мин Ен Юнг
}

1-2 МГУ имени М.В. Ломоносова, Российская Федерация

${ }^{1}$ Доктор экономических наук, доцент

E-mail: nico.73@mail.ru

${ }^{2}$ аспирант

Аннотация. Исследование пытается дать ответ на самый фундаментальный вопрос об энергетическом сотрудничестве между Россией и странами Северо-Восточной Азии, «действительно ли нужна модель сотрудничества в энергетической сфере?». Этот вопрос важен для понимания аспектов энергетического сотрудничества в этом регионе, потому что, идея создания данного сотрудничества основана на предположении, что между структурами спроса и предложения данных стран существует взаимодополняемость и взаимозависимость. Чтобы найти ответ на этот вопрос, мы проанализировали секторы спроса, потребления и предложения России и стран Северо-Восточной Азии по нефти и газу, как текущие доминирующие источники энергетики, и рассмотрели сектор ВИЭ (возобновляемых источников энергетики), как потенциальных будущих источников.

Ключевые слова: энергетическая стратегия, энергетическая модель сотрудничества, возобновляемые источники энергии, социально-экологические проблемы, взаимодополняемость и взаимозависимость в энергетической сфере. 